\title{
Status of Rhizome and Pseudostem Wet Rot Diseases of Banana
}

\author{
M. Loganathan*, R. Thangavelu, B. Padmanaban and S. Uma
}

ICAR-National Research Centre for Banana, Tiruchirappalli-620102, India

*Corresponding author

\section{A B S T R A C T}

\section{Keywords}

Rhizome rot, Pseudostem Wet Rot, Diseases,

Banana,

Pectobacterium carotovorum, Dickeya

Article Info

Accepted:

10 April 2019

Available Online:

10 May 2019
Rhizome rot and pseudostem rot diseases of banana are caused by bacterial pathogens mainly of Pectobacterium carotovorum or Dickeya chrysanthemi individually or together and $D$. paradisiaca respectively. The bacterial rot diseases are reported to cause $40-70 \%$ incidence in severely infected fields and their occurrence has been reported worldwide. Diagnosis of the disease is based on presence of the characteristic symptoms such as brown rotting in rhizome and foul odor in advance stages in case of rhizome rot while wet brown rotting on pseudostem in initial stage followed by breakage of pseudostem from the point of wet rot in later stage for pseudostem wet rot. The pathogens are characterized by morphology, gram staining, biochemical and molecular bases. Management of the diseases is focused by use of chemicals, cultural practices and beneficial microbes.

\section{Introduction}

Banana is the major fruit crop grown mainly in tropical and subtropical continents. The cultivation of the crop is mainly affected by biotic factors. Among the biotic factors, Fusarium wilt, bacterial wilt caused by Ralstonia or Xanthomonas and soft rot or rhizome rot caused by Pectobacterium or Dickeya are the major ones which affect the crop. Fusarium wilt disease is distributed worldwide including India and considerable studies on molecular characterization and management practices have been carried out (Dita et al., 2018). Similarly, though the
Ralstonia and Xanthomonas wilts are not encountered in India their occurrence and such studies have been documented elsewhere (Blomme et al., 2014; Blomme et al., 2017a; 2017b).

Soft rot or rhizome rot is a serious disease in countries of American (Fernandez, 1967; Rivera, 1978), African and Asian continents including India (Chattopadhyay and Mukherjee, 1986; Snehalatharani and Khan, 2010; Gokul et al., 2019). The soft rot or rhizome rot disease causes $>75 \%$ incidence in severely infected garden (Dita et al., 2013; Blomme et al., 2017a). The yield loss due to 
the bacterial soft rot was $82 \%$ in Guangzhou, China during 2009 (Lin et al., 2010). Bacterial pathogens such as Pectobacterium carotovorum, Dickeya chrysanthemi, D. zeae and $D$. paradisiaca have been reported as causal agents of the bacterial rot diseases in different parts of world. The disease development is associated with single or two causal agents together or intermediate group which depend on cultivars (genotype) and place (country) of occurrence. For an instance, Pectobacterium carotovorum pv. carotovorum has been reported as causal agent of rhizome rot in banana cv., Grand Naine (AAA) in India (Rajamanickam et al., 2018) while it was Dickeya sp. (earlier Pectobacterium chysanthemi) in Musa sapientum (cv. ABB) in China (Lin et al., 2010). Hence, it indicates, a thorough understanding on characterization of causal agent and etiology is required to classify the pathogen(s) and also to develop suitable management practices for combating the disease.

Hitherto, only few biocontrol, cultural and chemical based management practices have been attempted to manage bacterial rhizome rot or soft of banana (Arun et al., 2012; Patel et al., 2011; Rajamanickam et al., 2018). Keeping the above background, updates on characterization and management of rhizome rot or soft rot and pseudostem wet rot have been summarized in this document.

\section{Symptoms}

The bacteria produce two different symptoms viz., rhizome rot and pseudostem wet rot. Soft rot is a common symptom observed in both the types and it forms due to secretion of pectinases which degrade the middle lamella and primary cell walls followed by tissue maceration, wet and foul smell rotting (Hugouvieux-Cotte-Pattat et al., 2014). The pathogen attacks both rhizome and succulent tissue pseudostem.

\section{Rhizome rot}

It weakens the rhizome or corm. The affected young plants show leave yellowing and heart rot symptoms. The infected rhizome is cut open, yellow or brown coloured water soaked bigger spots with dark brown margin can be seen. Severely infected rhizomes may have characteristic symptoms such as decay of corm tissues, cavity formation and brown ooze with foul smell. Severely affected plants may topple down at maturity (Stover, 1972)

\section{Pseudostem wet rot}

The disease attacks pseudostem of young and pre-flowering plants. The pathogen enters into leaf sheath through wounds made during pruning or other cultural operations and multiplies in pseudostem. Initially it produces translucent spots at the base of the leaf sheath and pseudostem and later they become enlarged brown to dark brown spots cover large area of pseudostem. It may spread upward and down ward (Rivera and Ezavin, 1980) and interior part of leaf sheath causes rotting. Amber colour ooze comes out when the rotten area is pressed. Severely affected plant pseudostem may break due to wind or bunch weight.

\section{Causal agents}

\section{Rhizome rot/soft rot}

Different species or genus of causal organisms such as Pectobacterium carotovorum (earlier it was known as $E$. carotovora subsp. carotovora) and Pseudomonas cichorii in Korea (Chio et al., 1988) and intermediate group of $E$. carotovora and $E$. chrysanthemi in Iran (Hassanzadeh, 1990) and Dickeya sp. (earlier Erwinina chrysanthemi then Pectobacterium chrysanthemi) in China (Lin et al., 2010) and Papua New Guinea (Tomlinson et al., 1987) 
were reported. Besides, with in a country also the causal agents vary, in India, the causal agents of both $P$. carotovorum (E. carotovora subsp. carotovora) and Dickeya sp (E. chrysanthemi), and an intermediate group of those two in Karnataka and Andhra Pradesh (Snehalatharani and Khan, 2010), and $P$. carotovorum in Tamil Nadu and Kerala (Rajamanickam et al., 2018: Gokul et al., 2019) were reported.

\section{Pseudostem wet/soft rot}

Dickeya paradisiaca previously named as $E$. chrysanthemi pv. paradisiaca was reported as causal agent of pseudostem wet rot (Dickey and Victoria, 1980; Samson et al., 2005). Besides, in one case $D$. zeae was isolated from rotten area of pseudostem (Zhang et al., 2014).

\section{Characterization of causal agents}

Taxonomy of pathogen is important for studying epidemiology and to frame management strategies. Both Pectobacterium and Dickeya are the two major genera which cause rot diseases in banana and they belong to family Enterobacteriaceae and class Gammaproteobacteria.

\section{P. carotovorum}

The bacterium is non sporulating, gram negative rod with peritrichous and aerobic bacterium. It produces grayish white or cream to yellowish and mucoid raised colonies on Nutrient Agar and it forms characteristic pits on crystal violet pectate medium (Cuppels and Kelman, 1974).

\section{D. paradisiaca}

Bacterium is aerobic, rod, gram negative, peritrichous flagella and non sporulating type. Various growth patterns and colony colours were observed when the bacterium was grown on different media. On nutrient agar, it produces fine granular, irregular colonies initially and they turn to grey colour after $48 \mathrm{~h}$ and the colony centre rises after $96 \mathrm{~h}$. On Kings B and YDC, it produces diffusible brown and non diffusible blue pigments respectively while MNT medium was found to be selective medium for $D$. paradisiaca (Hevesi et al., 1981). Pathogenicity variation also observed among $D$. paradisiaca isolates as the isolates obtained from rhizome cortex could infect both rhizome and pseudostem whereas isolates recovered from pseudostem could only infect pseudostem (Rivera and Ezavin, 1980; Rivera et al., 1980).

\section{D. zeae}

Bacterial strains produce opaque, dull, wrinkled, slight convex, round or nearly round gray coloured colonies on nutrient agar medium while cultured at $32^{\circ} \mathrm{C}$ for $24-48 \mathrm{~h}$ but subsequent sub-culturing on the medium the gray colour disappeared. The strain $D$. zeae was distinguished from $D$. paradisiaca as the former one able to grow at $39^{\circ} \mathrm{C}$ and to catabolize cis-aconitate, myo inositol, mannitol and D-melibiose but the later one failed in the tests (Zhang et al., 2014). Though $D$. zeae infects both banana and paddy, phylogenetic analysis revealed $D$. zeae infecting banana in Guangdong, China was different from the strain infecting paddy collected in the same region (Zhang et al., 2014). The isolates of $D$. zeae could be distinguished by sequencing of $16 \mathrm{~S}$ rDNA, and genes of dnax, gry $\mathrm{B}$ and rec A (Zhang et al., 2014).

\section{Dickeya sp. (earlier, Erwinia chrysanthemi then Pectobacterium chrysanthemi)}

It is a straight rod with peritrichous flagella, facultatively anaerobic and gram-negative bacterium (Dickey, 1979). 
Although molecular characterization helps in identification of bacterial pathogens, comprehensive parameters including utilization of various biochemicals and growth at different temperature and salt concentration etc., as summarized in Table 1 are important for classification of banana bacterial rot pathogens at and beyond species level (Rivera, 1978; Dickey, 1979; Dickey and Victoria, 1980; Rivera and Ezavin, 1980; Tomlinson et al., 1987; Zhang et al., 2014; Liu et al., 2016; Blomme et al., 2017a).

\section{Pathogenicity of soft rot pathogen}

Injection of Dickeya sp., suspension $\left(10^{8}\right.$ $\mathrm{CFU} / \mathrm{ml}$ ) in rhizome of 40-60 d old plants established the characteristic symptoms of yellowing and wilting in ABB genome banana M. sapientum (Lin et al., 2010). In vitro inoculation of Pectobacterium carotovorum bacterial disc on rhizome bits and covering the disc with moist cotton and keeping the cotton covered inoculated rhizome bits in polythene bag to create humidity was able to produce rotting in Nendran cultivar within $8 \mathrm{~d}$ (Gokul et al., 2019). Similarly, inoculation of the $P$. carotovorum bacterial disc in rhizome of three month old Nendran and on pseudostem of two month old tissue culture Nendran produced the complete rotting symptoms on $37 \mathrm{~d}$ and $16 \mathrm{~d}$ after inoculation respectively (Gokul et al., 2019). As both Pectobacterium and Dickeya are having same strategy to cause disease and they share common host and geography, they tend to occur together in an environment. Also, several species of Dickeya are reported to cause soft rot. Hence possible combinations of different species of Dickeya and Pectobacterium causing rot diseases are yet unanswered.

\section{Etiology}

Bacterial rot pathogens enter via wounds caused due to pruning and detachment of senescent leaves, and natural openings. Poor sanitation, water deficit and dry spell for long time are also associated with severity of the disease. The bacteria can spread through irrigation water, tools, equipments and propagation materials without expressing symptoms (Charkowski, 2018). Banana is having different genome groups (ploidy levels) and response of the genome to the pathogens also varied. Banana cultivars of cooking $(\mathrm{ABB})$ and plantain $(\mathrm{AAB})$ were susceptible to $D$. paradisiaca than Cavendish (AAA) group (Blomme et al., 2017a). Cultivars with diploid genome (AA) were susceptible to E. chrysanthemi (Dickeya sp.) while $\mathrm{ABB}$ genome group was free from the disease and AAA showed reaction in between $\mathrm{AA}$ and $\mathrm{ABB}$ genome groups (Tomlinson et al., 1987).

\section{Management}

Earlier, soft rot was not a serious problem for banana cultivation while it was severe in vegetables, tubers, post harvest horticultural produces etc. However, of late, rhizome rot or soft rot become a major problem in tissue cultured derived banana seedlings planted gardens (Loganathan et al., 2018). Hence here possible management practices hitherto developed for controlling rhizome rot or soft rot have been documented.

Frequent visit to field at least once in two weeks is advised for early diagnosis of bacterial disease symptoms so as to take up sanitation measures to curtail further spread (Lehmann-Danziager, 1987) or to take up control measures in time. A sanitation programme through ELISA based indexing of planting materials for management of soft disease in Cavendish banana in Cuba was effective and successful (Pérez-Vicente, 2003). However, in case of D. paradisiaca, several stages of indexing were required as it could multiply in meristem tissue and it was reported as much as six indexing in different 
stages of mass multiplication were required to exclude the disease (Hernández et al., 1994). Also continuous disinfection of tools in sodium hypoclorite $(3.5 \%)$ during different stages of field operations especially during pruning was effective to control the disease up to $80 \%$ in plantain bananas (Fernández et al., 2013).

Table.1 Biochemical based differentiation of bacterial rot pathogens at species level

\begin{tabular}{|c|c|c|c|c|}
\hline Test & $\begin{array}{l}\text { E. chrysanthemi } \\
\text { (then Dickeya } \\
\text { sp.) }\end{array}$ & $\begin{array}{l}\text { E. carotovora pv. } \\
\text { carotovora (then } \\
P . \text { carotovorum) }\end{array}$ & $\begin{array}{l}\text { E. chrysanthemi } \\
\text { pv. paradisiaca } \\
\text { (then } D . \\
\text { paradisiaca) }\end{array}$ & D. zeae \\
\hline $\begin{array}{l}\text { Polypectate } \\
\text { degradation }\end{array}$ & + & + & + & + \\
\hline Soft rot on potato & + & + & $\mathrm{NA}^{*}$ & + \\
\hline Gelatin liquefaction & V & + & - & + \\
\hline Phosphatase activity & + & - & + & NA \\
\hline Gas from D glucose & + & - & + & NA \\
\hline $\begin{array}{l}\text { Growth at different } \\
\text { temperature }\end{array}$ & $36^{\circ} \mathrm{C}$ & $36^{\circ} \mathrm{C}$ & V & $39^{\circ} \mathrm{C}$ \\
\hline Growth in $5 \% \mathrm{NaCl}$ & V & + & - & NA \\
\hline Acid from maltose & - & $\mathrm{V}$ & - & + \\
\hline $\begin{array}{l}\text { Erythromycin } \\
\text { sensitivity }(60 \mu \mathrm{g})\end{array}$ & + & - & NA & NA \\
\hline Acid from Ethanol & + & - & + & NA \\
\hline Acid from Trehalose & - & + & - & $-{ }^{a}$ \\
\hline
\end{tabular}

*NA: Not available; + most positive; - most negative; V: Variable results; a-fail to utilize.

Several treatments involving chemicals such as combination of $0.15 \%$ acephate dip and $1 \%$ Bordeaux mixture or mancozeb $0.3 \%$ (Patel et al., 2011) and series of treatments with COC $(0.3 \%$,$) , antibiotic 600 \mathrm{mg} / \mathrm{l}$ (Streptomycin sulphate $9 \%+$ Tetracycline hydrochloride $1 \%$ ), $0.2 \%$ solution of Methyl Ethyl Mercuric chloride (MEMC), mono ammonium phosphate $(0.2 \%)$ and $50 \mathrm{~g}$ carbofuran/pit (Arun et al., 2012) have been advocated to manage the rhizome rot of banana. However, use of chemicals especially streptomycin and MEMC are having several demerits hence they could not be listed in recommended chemicals for use in banana (Central Insecticide Board and Registration Committee as on 31.05.2018: http://ppqs.gov.in/ contactus/central-insecticide-board-andregistration-committee-cibrc). Information on biocontrol based management of bacterial rot of banana is very scanty except few reports. Mini scale application of Pseudomonas fluorescens cells, Bacillus subtilis and VAM fungus (Glomus fasciculatum) (Nagaraj et al., 2012) and bio-priming of banana with plant growth promoting bacterial strains (B. subtilis PP and CL3) during primary and secondary hardening (Rajamanickam et al., 2018) showed considerable level of disease control which indicates that there is an urge in developing field deliverable bioformulation(s) or consortium for management of the rot diseases.

In conclusion, a holistic approach which reveals about the causal agents responsible for rhizome rot or Pseudostem wet rot which infect across the cultivars or genome groups is 
lacking in India and elsewhere. Weather parameters which are essential for development of soft rot in banana have not been worked out. Management of soft rot diseases through biocontrol agents' showed significant disease control in other crops such as vegetables and potato etc., hence similar or improved management practices can be attempted in banana.

\section{References}

Arun, W.A., Bohra, P., Umesha, K., Chandrashekar, S.C., Sathyanarayana, B.N, and Sreeramu B.S. 2012. Successful rescue and field establishment of native banana varieties severely affected by rhizome rot. Journal of Agriculture and Rural Development in the Tropics and Subtropics 113:147-154

Blomme G., Ocimati W., Sivirihauma C., Vutseme L., Mariamu B., Kamira M., van Schagen B., Ekboir J and Ntamwira J. 2017b. A control package revolving around the removal of single diseased banana stems is effective for the restoration of Xanthomonas wilt infected fields. Eur J Plant Pathol 149:385-400.

Blomme, G., Dita, M., Jacobsen, K.S., Pérez Vicente, L., Molina, A., Ocimati, W., Poussier, S. and Prior, P. 2017a Bacterial diseases of bananas and enset: Current state of knowledge and integrated approaches Toward Sustainable Management. Frontiers in Plant Science 8:1290.doi: 10.3389/fpls.2017.01290.

Blomme, G., Jacobsen, K., Ocimati, W., Beed, F., Ntamwira, J., Sivirihauma, C., Ssekiwoko, F., Nakato, V., Kubiriba, J., Tripathi, L., Tinzaara, W., Mbolela, F., Lutete, L. and Karamura, E. 2014. Finetuning banana Xanthomonas wilt control options over the past decade in
East and Central Africa. European Journal of Plant Pathology 139: 265281.

Charkowski, A.O. 2018. The Changing Face of Bacterial Soft-Rot Diseases. Annu. Rev. Phytopathol., 56:13.1-13.20. https://doi.org/10.1146/annurev-phyto080417-045906

Chattopadhyay, P.K. and Mukherjee, N. 1986. A pseudostem rot of banana due to Erwinia chrysanthemi pv. paradisiaca. Curr. Sci.55:789-790.

Chio, J. E., Park, J. S., and Kang, H. W. 1988. Bacterial soft rot of banana fruit caused by Erwinia carotovora subsp. carotovora and Pseudomonas cichorii. Korean J. Plant Pathol. 3:202-206.

Cuppels, D., and Kelman, A. 1974. Evaluation of Selective Media for Isolation of Soft-Rot Bacteria from Soil and Plant Tissue. Phytopathology 64:468-475

Dickey R.S., and Victoria, J.I. 1980. Taxonomy and Emended Description of Strains of Erwinia isolated from Musa paradisiaca Linnaeus. International Journal of Systematic Bacteriology 30:129-134.

Dickey, R. S. 1979. Erwinia chrysanthemi: A comparative study of phenotypic properties of strains from several hosts and other Erwinia species. Phytopathology, 69:324-329.

Dita M., Barquero, M., Heck D., Mizubuti, E.S.G. and Staver, CP. 2018. Fusarium wilt of banana: Current knowledge on epidemiology and research needs toward sustainable disease management. Frontiers in Plant Science. doi: 10.3389/fpls.2018.01468

Dita, M., Garming, H., Van den Bergh, I., Staver, C., and Lescot, T. 2013. Banana in Latin America and the caribbean: current state. Challeng. Perspect. Acta Hort., 986, 365-380. doi: 10.17660/ ActaHortic. 2013.986.39 
Fernández, B. D. 1967. Pudrición acuosa del pseudotallo del plátano (Musa paradisiaca) causada por una especie de Erwinia. Cenicafe 18, 39-46.

Fernández, J., Chavarría, U., Brown, D., and Dita, M. A. 2013. Evaluación Preliminar de Tratamientos Para el Manejo de la Pudrición por Erwinia en Plátano en Rivas, Nicaragua. Resúmenes del II Congreso Latinoamericano y del Caribe de Plátanos y Bananos, Armenia, Colombia. Maccarese: Bioversity International

Gokul G.G, Vimi Louis,, Namitha P.M., Deepu Mathew, Girija D., Shylaja M.R. and Abida. P.S. 2019. Variability of Pectobacterium carotovorum causing rhizome rot in banana. Biocatalysis and Agricultural Biotechnology 17:60-81.

Hassanzadeh, N. 1990. Characterization of a new soft rot Erwinia to banana in Iran. Iranian J. Plant Pathol. 26:13-18.

Hernández, R., Herrera, L., Pichardo, T., and Alvarado, Y. 1994. Diagnóstico de Erwinia chrysanthemi Burk et al., en el proceso de micropropagación in vitro del plátano (Musa spp.). Centro Agríc. $21,62-67$.

Hevesi, M., Rivera, N., and Perez, L. 1981. Medio selectivo para aislar y conserver a Erwinia chrysanthemi. Ciencia y Técnica en la Agricultura. Ser. Prot. Plant.4, 61-70.

Hugouvieux-Cotte-Pattat, N., Condemine, G and Shevchik, V.E. 2014. Bacterial pectate lyases, structural and functional diversity. Environ. Microbiol. 6:427-40

Lehmann-Danzinger, H. 1987. "The distribution of Moko disease in Central and South America and its control on plantains and bananas," in Proceedings of the CTA Seminar: Improving citrus and Banana Production in the Caribbean through Phyto-Sanitation, St Lucia, 130-152.
Lin, B. R., Shen, H. F., Pu, X. M., Tian, X. S., Zhao, W. J., Zhu, S. F., and Dong, M. M. 2010. First report of a soft rot of banana in Mainland China caused by a Dickeya sp. (Pectobacterium chrysanthemi). Plant Dis. 94:640.

Liu Q., Xiao W., Wu Z., Li S., Yuan Y. and Li, H. 2016. Identification of Dickeya dadantii as a causal agent of banana bacterial sheath rot in china. Journal of Plant Pathology 98 (3):503-510.

Loganathan M., Thangavelu R., Padmanaban B. and Uma S. 2018. Survey, isolation and characterization of rhizome rot of banana. In: National Symposium on Cutting edge approaches for sustainable plant disease management and ensuring farmers profit, held during 21-23 December 2018 at ICAR-National Research for Banana, Tiruchirappalli, Tamil Nadu, India, p215.

Nagaraj, M.S., Umashankar, N., Palanna, K.B. and Khan, A.N.A. 2012. Etiology and management of tip-over disease of banana by using biological agents. International Journal of Advanced Biological Research 2 (3):483-486.

Patel P.R., Sharma, H. and Shukla, A. 2011 Efficacy of chemicals against rhizome rot of banana. Karnataka Journal of Agricultural Sciences 24(5): 712-713.

Pérez-Vicente, L. 2003. "Manejo integrado de plagas y enfermedades en bananas y plátanos en Cuba," in Memorias del Taller Manejo Convencional y Alternativo de la Sigatoka Negra, Nematodos y Otras Plagas Asociadas al Cultivo de Musáceas en los Trópicos, (eds G. Rivas and F. E. Rosales, Guayaquil, 37-54.Hernández, R., Herrera, L., et al.,)

Rajamanickam S.A., Karthikeyan G.A., Kavino M.B. and Manoranjitham S.K. 2018. Biohardening of micropropagated banana using endophytic bacteria to induce plant growth promotion and 
restrain rhizome rot disease caused by Pectobacterium carotovorum subsp. carotovorum. Scientia Horticulturae 231:179-187

Rivera, N. 1978. Estudio comparativo de dos nuevas enfermedades bacterianas en áreas plataneras de Cuba. Agrotec. Cuba 10, 35-44.

Rivera, N., and Ezavin, M. 1980. Necrosis del cormo del plátano causada por Erwinia chrysanthemi. Ciencia Técnica Agric. Ser. Prot. Plantas 18, 59-69.

Rivera, N., García, A., and Gil, C. 1980. Caracterización patotípica de aislamientos de Erwinia chrysanthemi procedentes de plátano y maíz. Ciencia Técn. Agric. Ser. Prot. Plantas 3, 47-60.

Samson R., Legendre JB., Christen R., Fischer-Le Saux M., Achouak W. and Gardan, L. 2005. Transfer of Pectobacterium chrysanthemi (Burkholder et al., 1953) Brenner et al., 1973 and Brenneria paradisiaca to the genus Dickeya gen. nov. as Dickeya chrysanthemi comb. nov. and Dickeya paradisiaca comb. nov. and delineation of four novel species, Dickeya dadantii sp. nov., Dickeya dianthicola sp. nov., Dickeya dieffenbachiae sp. nov. and Dickeya zeae sp. nov. International Journal of Systematic and Evolutionary Microbiology 55:1415-1427.

Snehalatharani, A. and Khan, A.N. 2010. Biochemical and physiological characterization of Erwinia species causing tip-over disease of banana. Arch. Phytopathol. Plant Prot. 43:10721080.

Stover, R. H. 1972. Banana, Plantain, and Abaca Diseases. London: Commonwealth Mycological Institute, Kew p316.

Tomlinson D. L., King G.A. and Ovia A. 1987. Bacterial corm and rhizome rot of banana (Musa spp.) in Papua New Guinea caused by Erwinia chrysanthemi, Tropical Pest Management, 33:3, 196-199,

Zhang, J., Shen, H., Pu, X., Lin, B., and Hu, J. 2014. Identification of Dickeya zeae as a causal agent of bacterial soft rot in banana in China. Plant Dis. 98:436-442.

\section{How to cite this article:}

Loganathan, M., R. Thangavelu, B. Padmanaban and Uma, S. 2019. Status of Rhizome and Pseudostem Wet Rot Diseases of Banana. Int.J.Curr.Microbiol.App.Sci. 8(05): 764-771. doi: https://doi.org/10.20546/ijcmas.2019.805.090 